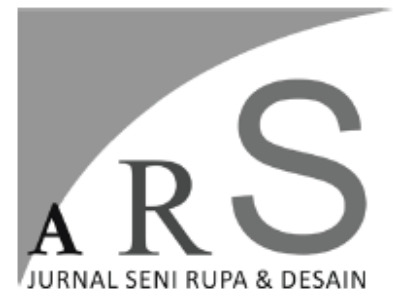

Volume 22 Nomor 2,

Agustus 2019

\section{TELUSUR SEJARAH BERDIRINYA MASJID AL MANSHUR WONOSOBO}

\author{
Zia Ghifari Muhammad \\ Program Studi Magister Desain, Institut Teknologi Bandung, Bandung, \\ Indonesia
}

\begin{abstract}
ABSTRAK
Sejarah merupakan bagian dari dinamika sosial budaya yang ada dimasyarakat. Faktanya, suatu bangunan dapat menjadi representasi dari nilai sejarah. Masjid Al Manshur merupakan salah satu bangunan ikonik di Kabupaten Wonosobo. Bagi masyarakat, masjid ini tak hanya berdiri sebagai tempat ibadah, namun juga merupakan saksi bisu dari lahirnya Kabupaten Wonosobo itu sendiri. Penelitian ini merupakan penelitian kualitatif yang sifatnya deskriptif. Usaha pencarian dan pengumpulan data dilakukan melalui proses observasi, wawancara mendalam, serta studi literatur. Tujuan dari penelitian ini untuk menelusuri, merangkum, serta memberikan gambaran terkait bagaimana Masjid Al Manshur sebagai bangunan bersejarah di Wonosobo. Masjid Al Manshur merupakan bangunan bersejarah yang menjadi narasi vital dimasyarakat. Beragam cerita tentang bagaimana masjid ini berdiri, merupakan bentuk respon apresiatif masyarakat bahwa masjid ini memegang peranan penting dalam perkembangan Kabupaten Wonosobo. Terdapat empat riwayat yang mengarah pada bagaimana masjid ini berdiri. Pertama, masjid didirikan pasca perang Diponegoro pada masa pemerintahan Bupati Wonosobo R.A. Mangunkusumo. Kedua, masjid didirikan pada masa Kewalen (kewalian). Ketiga, masjid didirikan pada masa kolonial Belanda yang awalnya berlokasi di sebelah barat alun-alun Wonosobo. Keempat, masjid ini didirkan oleh kalangan 'Alawiyin yang bermarga Ba'abud dan Bin Yahya dari daerah Batang dan Pekalongan pada sekitar tahun $1700 \mathrm{M}$ dalam rangka penyebaran Islam.
\end{abstract}

Kata kunci: sejarah, masjid, Wonosobo 
important role in development of the city. Four popular statement lead to how this mosque rise up. First, the mosque was established under the period of Wonosobo's Regent, R.A. Mangunkusumo, precisely after the Diponegoro war. Second, the mosque was established during the Kewalen (Kewalian) period. Third, this mosque was founded in a period of Dutch colonial era which was originally located west of the Wonosobo square. Fourth, the mosque is established by the Alawiyin group, surnamed Ba'abud and Bin Yahya from the Batang and Pekalongan regions around $1700 M$ in the context of the spread of Islam.

Keywords: history, mosque, Wonosobo

\section{Pendahuluan}

Sejarah merupakan bagian dari dinamika sosial budaya yang ada dimasyarakat. Setiap yang ada, setiap yang tinggal, pada akhirnya akan menjadi bagian dari sebuah sejarah. Baik yang hidup ataupun yang bersifat kebendaan, bilamana telah melewati suatu rentang waktu, akan menorehkan nilai cerita yang dapat berasosiasi dengan kesejarahan. Menurut (Piliang, 2009), sebuah budaya melingkupi sistem sosial dari masyarakatnya, sistem moral, techno-material system, sistem seni, sistem bahasa, dan sistem mental yang membangun masyarakat tersebut. Maka melihat hal tersebut, keberadaan sejarah akan lekat sebagai latar dari bagaimana perkembangan masyarakat dan lingkungan, mulai dari sistem moral, sistem seni sampai sistem mental.

Suatu bangunan dibuat oleh manusia dengan memperhatikan tujuan-tujuan tertentu. Tujuan itu tentunya memperhatikan bagaimana konteks hubungan bangunan tersebut dengan manusia. Masjid merupakan contoh bangunan yang dapat memiliki dampak serta peran besar bagi peradaban serta dinamika sosial budaya masyarakat. Masjid dapat dikatakan sebagai produk kebudayaan yang mengandung tatanan nilai (intangible) atau dengan kata lain dapat juga dikatakan sebagai bagian dari suatu peradaban (tangible).

Seperti yang secara umum kita ketahui, adanya masjid merupakan suatu tanda bagi berkembangnya agama Islam diarea tersebut. Masjid pada dasarnya merupakan tempat beribadah bagi umat Islam. Seperti sabda Nabi Muhammad SAW : "Dimanapun engkau bersembahyang, tempat itulah masjid". Kata masjid sendiri disebut sebanyak dua puluh kali didalam Al Qur'an, berasal dari kata sajada-sujud, yang berarti patuh, taat, serta tunduk penuh hormat dan takzim. Sujud dalam syariat yaitu berlutut, meletakkan dahi, kedua tangan ke tanah adalah bentuk nyata dari kata tersebut diatas. Oleh karena itu, bangunan dibuat khusus untuk shalat disebut masjid yang artinya ; tempat untuk sujud. (Sumalyo, 2006)

Keberadaan masjid pada suatu lingkungan sosial masyarakat, dapat ditinjau dari berbagai hal. Salah satunya bila memperhatikan bagaimana posisi masjid pada konteks sejarah. Diketahui bangunan masjid juga bisa menjadi sebuah representasi dari nilai sejarah suatu daerah tertentu. Terlebih bila merujuk pada Keputusan Direktur Jenderal Bimbingan Masyarakat Islam. Nomor Dj.Ii/802 Tahun 2014. Tentang. Standar Pembinaan Manajemen Masjid, salah satu jenis masjid adalah masjid bersejarah adalah apabila sebuah masjid berada dikawasan peninggalan kerajaan/Wali/penyebar agama Islam/memiliki nilai besar dalam sejarah perjuangan bangsa. Dibangun oleh para Raja/Kesultanan/para Wali penyebar agama Islam serta para pejuang kemerdekaan. (Kementerian Agama, 2014)

Masjid Al Manshur merupakan masjid yang berada di Kabupaten Wonosobo yang telah berdiri sejak tahun 1820. Melihat konteks waktu berdirinya bangunan, masjid ini dapat dikatakan sebagai bangunan yang cukup berumur. Dimana faktanya, masjid ini juga telah termasuk dalam bangunan cagar budaya 
yang mana berdirinya pun juga bersamaan dengan lahirnya Kabupaten Wonosobo. Bahkan, dikatakan pula bahwa masjid ini jauh lebih dahulu hadir dibanding lahirnya Kabupaten Wonosobo. Hal tersebut tentunya membawa salah satu fakta bahwa Masjid Al Manshur merupakan bangunan yang menjadi representasi dari nilai sejarah serta perkembangan sosial budaya dari Kabupaten Wonosobo itu sendiri.

Menelusuri bagaimana berdirinya Masjid Al Manshur, dapat dikatakan sebagai suatu tugas kesejarahan yang menarik untuk dilakukan. Banyak narasi yang berkembang dimasyarakat tentang bagaimana serta kapan masjid ini berdiri. Pro kontra pun tak luput meramaikan apa yang dibicarakan masyarakat terkait Masjid Al Manshur. Saat ini pun, bangunan masjid telah menjadi salah satu bangunan ikonik di Kabupaten Wonosobo. Keberadaannya yang vital turut menjadi bagian dari perkembangan sosial budaya dimasyarakat. Berdasarkan hal tersebut, penelitian ini hadir guna mencari, menggali, serta merangkum berbagai informasi yang ada tentang sejarah berdirinya Masjid Al Manshur Wonosobo. Sebagai penelitian sejarah, penelitian ini diharapkan mampu menyajikan data aktual dan runtut terkait kenyataan yang sebenarnya terkait objek penelitian.

\section{Bahan dan Metode Pembahasan}

Penelitian ini mengambil bentuk penelitian kualitatif, data-data yang ada akan dipaparkan secara deskriptif guna mencapai pemahaman yang diinginkan. Masjid $\mathrm{Al}$ Manshur merupakan objek penelitian yang berusaha dikaji terkait bagaimana sejarah berdirinya masjid ini. Teknik penelitian sejarah yang dipakai sendiri berupa observasi langsung terhadap objek penelitian, kajian kepustakaan atau literatur, serta wawancara mendalam dengan berbagai narasumber. Tujuan metode historis adalah untuk membuat rekonstruksi masa lampau secara sistematis dan objektif dengan cara mengumpulkan, mengevaluasi, memperifikasi, serta mensistesiskan bukti-bukti untuk menegakkan fakta-fakta dan memperoleh kesimpulan yang kuat. Suryabrata, 1998)

Observasi terhadap Masjid Al Manshur dilakukan sebagai tahap awal dari penelitian ini. Disini peneliti berusaha untuk melihat secara langsung bagaimana keadaan masjid pada era sekarang. Selain keadaan bangunan masjid, bagaimana aktivitas serta hubungan masjid dengan sosial masyarakat pun juga dilihat sebagai bentuk pencarian data kesejarahan. Secara umum tahapan ini akan memberikan gambaran kondisi terkini masjid yang menunjukkan aktualisasi bangunan ditengah dimanika sosial budaya masyarakat Wonosobo.

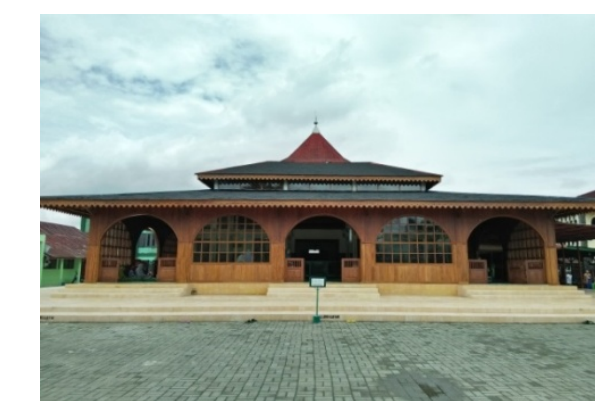

Gambar 1. Masjid Al Manshur Wonosobo saat ini (Sumber : Dokumen Zia Ghifari)

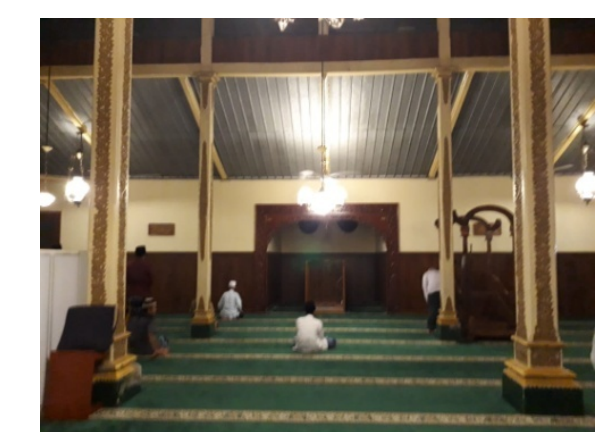

Gambar 2. Serambi dalam Masjid Al Manshur Wonosobo

(Sumber : Dokumen Zia Ghifari)

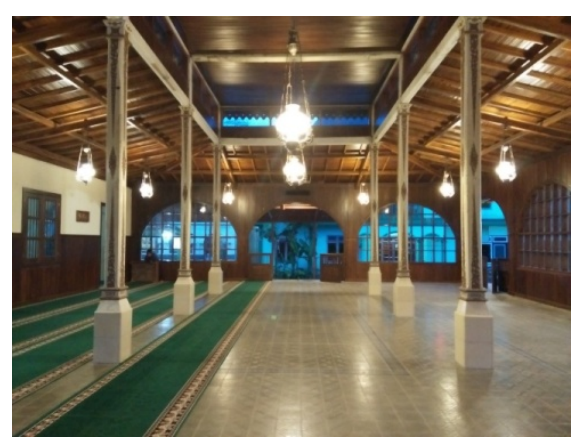

Gambar 3 Serambi luar Masjid Al Manshur Wonosobo

(Sumber : Dokumen Zia Ghifari) 
Tahapan berikutnya yang dilakukan dalam penelitian ini adalah kajian kepustakaan atau literatur. Teknik kepustakaan yaitu suatu cara pengumpulan data dan informasi dengan bantuan bermacam-macam material yang terdapat di ruang kepustakaan misalnya majalah-majalah, catatan-catatan, koran, dokumen, kisah sejarah dan sebagainya yang relevan dengan penelitian. (Koentjaraningrat, 1983)

Proses pencarian dokumen yang berkaitan dengan objek penelitian dapat dikatakan cukup sulit dilakukan. Ditemukan sedikitnya dua buah sumber literasi yang dapat dipakai untuk penelitian ini. Pertama, buku karangan Ahmad Muzan yang berjudul "Diaspora Islam Damai". Buku ini dapat dikatakan sebagai dokumen yang cukup lengkap guna melihat bagaimana berdirinya serta perkembangan dari Masjid Al Manshur. Meskipun pada dasarnya buku ini tidak membahas Masjid Al Manshur sebagai inti kajian, melainkan lebih kepada persebaran agama Islam di Wonosobo. Berdasarkan buku ini, didapat beberapa point penting yang menyangkut kajian penelitian. Dijelaskan disini bahwa pada konteks berdirinya masjid, ternyata terdapat beberapa pendapat yang menyertai hingga saat ini. Selain itu dijelaskan pula profil masjid secara umum seperti kegiatan apa saja yang selama ini berlangsung didalamnya.

Dokumen literatur berikutnya yang berhasil didapatkan adalah buku berjudul Legenda Wonosobo. Buku karangan Lis Retno Wibowo dan Dwi Putranto Bimo Sasongko ini sebenarnya juga tidak secara khusus menjelaskan bagaimana Masjid Al Manshur berdiri. Meskipun begitu, konteks bahasan tentang sejarah Wonosobo secara tidak langsung menyinggung juga bagaimana masjid ini berdiri. Hal ini tentu karena proses berdirinya masjid dan lahirnya Kabupaten Wonosobo sendiri yang memang dalam satu periode atau saling berdekatan. Berdasarkan hal itu, didapat fakta bahwa tokoh-tokoh yang diceritakan dalam buku ini pun ternyata memiliki merupakan tokoh-tokoh yang juga terlibat dalam berdirinya Masjid Al Manshur. Informasi ini tentunya penting mengingat pada literatur sebelumnya didapat beberapa narasi terkait berdirinya masjid. Dimana dari buku kedua ini dapat mempersempit analisa penelitian terkait kecenderungan simpulan topik sejarah berdirinya Masjid Al Manshur.

Proses selanjutnya merupakan tahapan wawancara. Narasumber terpilih akan dimintai keterangan sebanyak mungkin terkait objek penelitian. Utamanya tentu perihal sejarah berdirinya Masjid Al Manshur. Menariknya disini, peneliti berhasil menemui salah satu keturunan pendiri masjid, Bapak Syarief Hidayatullah. Berdasarkan wawancara dengan yang bersangkutan, didapat informasi penting yang mengarahkan penelitian ini menjadi lebih jelas lagi. Pada kasus sejarah berdirinya masjid, beliau menyampaikan bahwa tahun 1820 merupakan tahun berdirinya Masjid Al Manshur. Beberapa keterangan yang didapat dari narasumber menunjukkan adanya kesamaan dengan informasi-informasi yang didapat dari kajian kepustakaan. Meskipun beberapa keterangan lain juga bernilai kontradiktif.

\section{Hasil dan Pembahasan}

Kajian penelitian ini melahirkan beberapa analisa terkait sejarah berdirinya Masjid Al Manshur. Data-data yang dikumpulkan dari kajian kepustakaan dan juga wawancara pada narasumber, menunjukkan fakta bahwa berdirinya Masjid Al Manshur ternyata rekat dengan persebaran Islam di Wonosobo. Masjid ini dianggap memiliki pertalian erat dengan persebaran Islam, juga merupakan saksi bisu dari sejarah berdirinya Wonosobo itu sendiri. Serangkaian fakta sejarah terkumpul menunjukkan bahwa masjid yang berdiri jauh sebelum kemerdekaan ini, merupakan bangunan yang sendirinya lebih tua dibandingkan dengan Wonosobo.

Melalui serangkaian kajian yang dilakukan, penelitian ini menghimpun empat narasi terkait sejarah berdirinya Masjid $\mathrm{Al}$ Manshur yaitu : Pertama, diketahui bahwa 
berdiri masjid ini terjadi pada saat Wonosobo diperintah oleh Bupati R.A. Mangunkusumo pasca perang Diponegoro. Disini beliau menunjuk K.H. Manshur bin Kyai Marhamah menjadi penghulu Landrad dan sekaligus menjadi imam masjid. K.H. Manshur sendiri merupakan menantu dari Sayid Hasyim bin Idrus bin Muhsin Ba'abud yang menikah dengan putrinya Syarifah Khotijah. Perlu diketahui, Sayid Hasyim bin Idrus bin Muhsin Ba'abud merupakan keturunan Nabi Muhammad SAW berasal dari Hadramaut, Yaman yang datang ke Indonesia menyebarkan agama Islam. Sayid sendiri merupakan sebutan bagi bangsawan keturunan Arab. Kedudukan Kyai Manshur sebagai pengulu Landrad inilah yang menyebabkan beliau menjadi imam sekaligus pengelola masjid. Karena faktor historis yang kemudian menjadikan nama Mbah Kyai Manshur diabadikan menjadi nama masjid ini semenjak tahun 1972 (Dokumen akte notaris yayasan). Fakta tersebut tentu menunjukkan bukti bahwa berdirinya masjid ini erat kaitannya dengan penyebaran Islam di Wonosobo.

Kedua, masjid ini didirikan pada masa Kewalen (kewalian), pada masa itu datanglah seorang utusan dari kerajaan Demak Bintoro untuk menyebarkan agama islam di pedalaman pulau Jawa (Jawa Tengah), pada saatnya mubaligh itu menetap disebuah tempat dan mendirikan Masjid yang kemudian diberi nama saat ini Masjid Al Manshur. Versi kedua ini sebenarnya masih perlu di tela'ah lebih dalam lagi terkiat siapa wali yang dimaksud dan bagaimana prosesnya sampai hadirnya Masjid Al Manshur. Namun yang menjadikan versi kedua ini menarik tentunya fakta yang kembali menunjukkan indikasi bahwa proses penyebaran Islam memiliki peran dalam berdirinya Masjid Al Manshur. Seperti yang kita tahu, bahwa para wali pada masanya memiliki peran besar dalam proses persebaran serta pertumbuhan agama Islam.

Ketiga, diberitakan bahwa pada masa kolonial Belanda, terdapat sebuah masjid disebelah barat alun-alun Wonosobo (yang mana sekarang ini lokasi tersebut telah menjadi Komando Distrik Militer/KODIM). Bahkan masjid tersebut telah berdiri lengkap dengan pondok pesantrennya. Namun atas dasarnya politik penjajahan, Belanda membongkar masjid tersebut karena tidak sesuai dengan rencana pembentukan kota oleh penjajah. Disinilah kemudian, Kyai Manshur muncul dan mewakafkan tanahnya sebagai tempat berdirinya kembali masjid tersebut. Lokasinya berada didaerah Kauman yang kemudian membuat masjid ini bernama Masjid Kauman. Namun kemudian seiring berjalannya waktupun Masjid ini dikenal dengan nama Masjid Al Manshur, merujuk pada jasa Kyai Manshur yang telah mewakafkan tananya.

Keempat, memiliki narasi yang hampir serupa dengan versi pertama, pada sekitar tahun $1700 \mathrm{M}$ telah datang didaerah Wonosobo dari kalangan 'Alawiyin yang bermarga Ba'abud dan Bin Yahya dari daerah Batang dan Pekalongan untuk menyebarkan islam didaerah pegunungan Dieng dan sekitarnya. Kemudian menuju ke daerah selatan dan menetap di sebuah tempat yang diberi nama Kauman (dari bahasa arab Qaum) sebuah nama yang diberikan khusus untuk keturunan Arab di Indonesia. Di tempat inilah kemudian didirikan sebuah tempat ibadah yang kemudian merupakan cikal bakal berdirinya Masjid Kauman. Mereka diberi tugas khusus melakukan syiar Islam di daerah pegunungan Dieng dan menuju arah selatan. Belakangan daerah itu dikenal dengan nama Kauman. Ketika mengawali syiar Islam ditempat barunya tersebut, Sayid Hasyim Ba'abud (w.1291H) dan Yahya membangun padepokan sebagai pusat kegiatan pengajaran agama Islam di kawasan Kauman. Padepokan itulah yang kemudian dijadika sebagai cikal bakal Masjid Al Manshur Wonosobo. Sepeninggal Sayid Hasyim yang tinggal didaerah Kauman dilanjutkan putranya Sayid Ali bin Hasyim Ba'abud (w.1276H).

Pemaparan tersebut merupakan hasil elaborasi data penelitian melalui proses kajian pustaka "Diaspora Islam Damai" karya Muzan ditahun 2011, "Legenda Wonosobo" 
karya Lis Retno Wibowo dan Dwi Putranto Bimo Sasongko tahun 2013 serta obervasi dan wawancara dengan pihak-pihak terkait. Berdasarkan hal tersebut, terjadi beberapa perbedaan terkait bagaimana sejarah berdirinya Masjid Al Manshur. Terlebih lagi, kontradiksi terkuat muncul dari hasil kajian pustaka bila dipadukan dengan hasil wawancara.

Kegiatan wawancara yang dilakukan pada tokoh setempat, utamanya terhadap Bapak Syarief Hidayatullah selaku keturunan langsung pendiri masjid, menunjukkan adanya penolakan terhadap kajian pustaka yang ada. Dalam penuturan beliau, berdirinya masjid hanya ada satu versi, dimana masjid berdiri ditahun 1820. Awalnya masjid berada didekat alun-alun, yang mana kemudian oleh kebijakan Belanda bangunan masjid dipindah ke Kauman hingga sekarang. Penuturan ini tentunya berbeda dengan pustaka yang ada. Meskipun begitu, versi ketiga dari kajian pustaka sebenarnya merupakan versi yang cukup mendekati dengan hasil wawancara tersebut.

Perbedaan yang ada tersebut sebenarnya sedikit demi sedikit juga membuka tabir lain terkait sejarah berdirinya Masjid Al Manshur. Terutama terkait fakta perpindahan lokasi masjid, dari didekat alun-alun hingga pindah ke daerah Kauman. Disini, sebenarnya didapatkan suatu interpretasi nilai kesejarahan terkait hal tersebut. Posisi awal masjid bila merujuk pada kajian pustaka, maka tepatnya sebenarnya ada di sebelah barat alun-alun. Dimana kemudian saat terjadi proses pemindahan masjid ke daerah Kauman (ada disebalah barat laut, atau bisa dikatakan pula di arah perjalanan ke utara dari alun-alun), maka fenomena tersebut dapat diinterpretasikan sebagai suatu dampak politik kebijakan Belanda. Terlebih lagi, pasca kepindahan tersebut Belanda membangun gereja (hingga sekarang ada) dilokasi bekas masjid. Artinya, Belanda mencoba merubah tatanan pusat kota tradisional agar memudahkan tujuan politisnya.

Beralih pada hasil wawancara, maka terdapat perbedaan dimana dituturkan bahwa lokasi masjid awalnya ada di selatan alun-alun. Hal ini tentunya tidak sesuai dengan sistem tatanan pusat kota yang mana seharusnya masjid dalam area tersebut ada di sebelah barat alun-alun. Disini kemudian, Belanda mencoba memindahkan masjid pada lokasi yang lebih representatif dan sesuai, yaitu didaerah Kauman. Alasannya, tentu karena daerah Kauman lokasinya masih terhitung daerah barat dari alun-alun, meskipun barat laut dan memang area yang tepat di barat alun-alun sudah menjadi area pemukiman Belanda (sesuai dengan observasi dilapangan). Secara umum kepindahan tersebut tentu terasa aneh, namun sebenarnya secara tak langsung kejadian tersebut dapat dimaknai sebagai suatu usaha dari pemerintahan Belanda guna menarik simpati rakyat dengan memperbaiki pola tatanan pusat kota agar menjadi seperti seharusnya.

Meskipun terdapat perbedaan, sebenarnya masih ada satu benang merah yang dapat ditarik. Berbagai versi yang menyangkut berdirinya Masjid Al Manshur, sebenarnya akan selalu terkait dengan perkembangan Islam di Wonosobo. Selain karna memang masjid merupakan tempat ibadah umat Islam, juga karena momen dari berdirinya masjid, persebaran Islam di Wonosobo, sampai lahirnya Kabupaten Wonosobo berada dalam satu rangkaian peristiwa. Momen-momen yang saling berdekatan tersebut pada akhirnya saling memberikan pengaruh dan memperkaya latar sejarah, sosial, budaya sampai politik yang terjadi pada saat itu.

\section{Kesimpulan}

Berdasarkan hasil elaborasi data yang telah terkumpul, kesimpulan dari penelitian ini adalah bahwa berdirinya Masjid Al Manshur erat kaitannya dengan awal mula persebaran Islam di Wonosobo. Dimana keberadaan dari masjid ini sendiri menjadi pertanda dari hadirnya peradaban baru, keislaman, di Wonosobo. Meskipun terdapat beragam versi terkait bagaimana Masjid $\mathrm{Al}$ Manshur berdiri, peneliti mengerucutkan kepada empat versi besar yang didapat dari 
proses wawancara, studi pustaka dan juga observasi objek penelitian. Dari sini, tuturan terkait berdiri masjid pun mengarah pada satu kesimpulan, bahwa Masjid Al Manshur berdiri sejak tahun 1820. Disini tokoh-tokoh persebaran Islam di Wonosobo berperan besar atas berdirinya masjid.

Persebaran Islam di Wonosobo dibawa oleh kalangan 'Alawiyin yang bermarga Ba'abud dan Bin Yahya, keduanya dari daerah Batang dan Pekalongan yang datang guna menyebarkan islam didaerah pegunungan Dieng dan sekitarnya. Menariknya, informasi yang didapat selama penelitian menunjukkan bahwa tokoh yang menjadi dalang terbentuknya Wonosobo, Kyai Walik, Kyai Karim, dan Kyai Kolodente, diduga salah satunya merupakan bagian dari rombongan Sayid Hasyim yang datang untuk berdakwah. Sehingga disini, relasi antara tokoh-tokoh tersebut, kuat membentuk koneksi dari lahirnya Wonosobo, persebaran Islam, dan juga terbentuknya Masjid Al Manshur. Alurnya, bahwa ketiga tokoh tersebut merupakan bagian dari rombongan dari penyebar Islam di Wonosobo. Awalnya membuka daerah Wonosobo (belum dalam konteks membentuk daerah secara pemerintahan), kemudian menyebarkan Islam dan dibangunlah Masjid Al Manshur sebagai bagian dari perjuangan keislaman tersebut.

Fenomena perpindahan lokasi masjid pun juga menunjukkan adanya berbagai kepentingan yang mempengaruhi berdiri serta berkembangnya Masjid Al Manshur. Selain faktor sosial budaya yang tentunya mempengaruhi, keadaan sistem pemerintahan atau faktor politik saat itu, juga turut mempengaruhi. Namun kembali lagi, meskipun begitu, berdirinya masjid ini tetap erat kaitannya dengan perkembangan Islam di Kabupaten Wonosobo. Bahkan dalam konteks perpindahan lokasi masjid, disinyalir campur tangan Belanda tersebut juga merupakan bagian politik menarik simpati masyarakat melalui sentuhan kebijakan pada tempat ibadah (aspek keagamaan atau Islam).
Pada proses kedepannya, penelitian ini masih dapat dikembangkan lagi secara luas dan dalam. Dimana analisa terkait berbagai aspek yang mempengaruhi berdirinya masjid ataupun bagaimana proses berkembangnya masjid hingga bertahan sampai sekarang merupakan contoh topik kajian yang bertautan. Diharapkan juga agar semangat menela'ah sejarah yang ada pun dapat terus terjaga dengan adanya penelitian-penelitian sejarah semacam ini. Karena selayaknya manusia, yang hidup didunia, tentu baiknya melestarikan nilai sejarah yang ada dalam kehidupannya.

\section{Daftar Pustaka}

Kementerian Agama. (2014). Standar Pembinaan Manajemen Masjid.

Koentjaraningrat. (1983). Metode-metode Penelitian Masyarakat. Jakarta: Gramedia.

Piliang, Y. A. (2009). Semiotika Komunikasi Visual. Yogyakarta: Jalasutra.

S. Suryabrata. (1998). Metodologi Penelitian. Yogyakarta: Radja Grafindo.

Sumalyo, Y. (2006). Arsitektur Mesjid dan Monumen Sejarah Muslim. Yogyakarta: Gadjah Mada University Press. 